\title{
DISCURSIVE PRACTICES OF NEW AND TRADITIONAL MEDIA
}

\author{
Aleksandr V. Mlechko \\ Volgograd State University, Volgograd, Russia \\ Ivan N. Shamaev \\ Volgograd State University, Volgograd, Russia
}

\begin{abstract}
The paper analyzes the discursive practices of traditional and new media. The special attention is paid to the change of discourse paradigms within which we can observe the inevitable rotation of both discursive practices and the models of media discourse. Modern medialogy involves a variety of interdisciplinary approaches and methods of analysis. An important place among them is occupied by linguistic methodology, in particular, the discourse analysis, which allows conducting an authentic study of a variety of media phenomena operating in the framework of multi-level communicative models. These processes and mechanisms are especially clearly manifested in the comparative analysis of traditional and new media.

Using the example of discursive organization of the journal Sovremennye zapiski ('Contemporary Notes'), the materials of the community of professional mass media Vysota 102 ('Height 102'), as well as public pages not associated with professional media, but oriented on dissemination of socially important content Tipichny Volgograd ('Typical Volgograd') and NEtipichny Volgograd ('Non-Typical Volgograd'), we've shown that media discursive practices, being heterogeneous structures, not only correspond, but also form the semantic potential of specific media. In the case of traditional media, transdiscursivity is the leading discursive practice, since it allows carrying out effective oscillation of meanings from one discourse to another. In the case of new media, such practices as polydiscursivity and interdiscursivity are priority ones. They form authentic communicative models in a situation of global transformation of the media space. At the same time, the media discourse, the consumer discourse, and the discourse aimed at the formation of identity in the sociocultural space, become dominant.
\end{abstract}

Key words: discourse, transdiscursivity, interdiscursivity, polydiscursivity, text, social network, semantics, communication.

Citation. Mlechko A.V., Shamaev I.N. Discursive Practices of New and Traditional Media. Vestnik Volgogradskogo gosudarstvennogo universiteta. Seriya 2, Yazykoznanie [Science Journal of Volgograd State University. Linguistics], 2018, vol. 17, no. 3, pp. 119-129. (in Russian). DOI: https://doi.org/10.15688/jvolsu2.2018.3.12

\section{ДИСКУРСИВНЫЕ ПРАКТИКИ ТРАДИЦИОННЫХ И НОВЫХ МЕДИА}

\author{
Александр Владимирович Млечко \\ Волгоградский государственный университет, г. Волгоград, Россия \\ Иван Николаевич Шамаев \\ Волгоградский государственный университет, г. Волгоград, Россия
}

Аннотация. В статье проведено сопоставление дискурсивных практик традиционных и новых медиа,
при этом особое внимание уделено смене дискурсивных парадигм, внутри которых происходит неизбежная
ротация не только дискурсивных практик, но и моделей медиадискурса. На примере дискурсивной организа-
ции «толстого» журнала «Современные записки» и материалов сообества профессиональных СМИ «Вы-
сота $102 »$, РИАТЦ, а также пабликов, не связанных с профессиональныхми медиа, но ориентированных на 
распространение социально значимого контента - «Типичный Волгоград» и «НЕтипичный Волгоград» показано, что медийные дискурсивные практики, представляя собой гетерогенные структуры, разными способами не только корреспондируют, но и формируют семантический потенциал конкретных медиа. Установлено, что в традиционных медиа ведущей дискурсивной практикой выступает трансдискурсивность, поскольку именно она позволяет осуществлять эффективную осцилляцию смыслов от одного дискурса к другому. В новых медиа приоритетными являются такие практики, как полидискурсивность и интердискурсивность: они формируют аутентичные коммуникативные модели в ситуации глобальной трансформации медийного пространства. При этом доминирующими становятся такие дискурсы, как медийный, консьюмеристкий, а также направленный на формирование идентичности в социокультурном пространстве.

Ключевые слова: дискурс, трансдискурсивность, интердискурсивность, полидискурсивность, текст, социальная сеть, семантика, коммуникация.

Цитирование. Млечко А. В., Шамаев И. Н. Дискурсивные практики традиционных и новых медиа // Вестник Волгоградского государственного университета. Серия 2, Языкознание. - 2018. - Т. 17, № 3. - С. 119 129. - DOI: https://doi.org/10.15688/jvolsu2.2018.3.12

\section{Введение}

Современная медиалогия предполагает сочетание междисциплинарных подходов и методов анализа - культурологических, философских, антропологических, социологических, литературоведческих и др. Важное место среди них занимает лингвистическая методология, в частности, дискурс-анализ, позволяющий провести аутентичное исследование самых разных медийных феноменов, функционирующих в рамках полиуровневых коммуникативных моделей.

Особый научный интерес вызывает смена дискурсивных парадигм, внутри которых происходит неизбежная ротация не только дискурсивных практик, но и моделей медиадискурса. Наиболее отчетливо эти процессы и механизмы проявляются при сопоставительном анализе традиционных и новых медиа.

\section{Дискурсивные практики традиционных медиа}

Для демонстрации механизмов функционирования дискурсивных практик в традиционных медиа выбран эмигрантский журнал «Современные записки», поскольку он был самым крупным и влиятельным изданием русского зарубежья (некоторые исследователи относят его к самым крупным в русской журналистике вообще). Это журнал-долгожитель (выходил с 1920 по 1940 год), на его страницах опубликованы художественные, философско-публицистические, мемуарные и критические произведения наиболее известных писателей, мыслителей, критиков и в це- лом деятелей культуры русской эмиграции первой волны. Невозможность переоценки той роли, которую сыграл журнал в истории русского рассеяния, хорошо осознавалась самими изгнанниками.

Композиционная структура журнала была трехчленной. Открывал каждый выпуск традиционный для «толстых» журналов художественный (без названия) раздел, состоящий из двух немаркированных частей - проза и поэзия (в этом разделе - также без дополнительного деления - публиковалась и публицистика, в том числе философская). За ним следовал второй по объему и очередности раздел «Культура и жизнь», в состав которого входили статьи на политические, философские, экономические темы, а также посвященные культуре. Третий раздел - «Критика и библиография» - содержал большое количество обзоров и рецензий на книжные «новинки» как на русском, так и на иностранных языках.

В журнале, как ни в каком другом эмигрантском издании, принимали участие и активно печатались почти все самые видные литераторы и мыслители русского зарубежья. Объединение их текстов с опорой только на исторический (внешний) подход к материалу возможно лишь на двух основаниях, которые вытекают из программных заявлений редакции: дистанцирование от радикализма правого толка и - крайне шаткое и расплывчатое акцентирование «демократических» и «освободительных» идеалов. Если мы примем исторический подход для текстового анализа, то будем вынуждены констатировать принципиальную разноголосицу многочисленных тек- 
стов, напечатанных в «Современных записках», их смысловую несовместимость или совместимость минимальную (что общего, например, между статьями М. Вишняка и $Ф$. Степуна или романами И. Шмелева и В.В. Набокова, помещенными в единое текстуальное пространство журнала?), повышенный уровень «текстуальной энтропийности» этого пространства, невозможность его структурации, отсутствие в нем системных эффектов, поиском которых в различных областях культуры так озабочена социогуманитарная мысль вот уже как минимум два столетия. Наши рассуждения продолжают этот поиск на текстологическом уровне абстракции.

Мы сосредоточимся на смысловой структуре журнальных текстов, проводя поиск их единства в области текстов художественных, на что у нас имеется несколько веских оснований. Во-первых, как мы уже отмечали, именно «беллетристический» раздел открывал каждый выпуск, именно ему была отведена большая часть журнального листажа, из чего следует, что остальные (прежде всего «публицистический») разделы всецело (для нас важно подчеркнуть семантический характер этой экспансии) подчинялись художественному. Как отмечает отечественный исследователь Ю.А. Азаров, «большинство читателей-эмигрантов, не принимая политической позиции редакции, высоко оценило литературные публикации “Современных записок”. Популярность журнала была в первую очередь обусловлена достоинствами не общественно-политического, а литературного отдела» [Азаров, 2002, с. 285]. Во-вторых, именно этот раздел был в минимальной степени «контролируем» соредакторами «Современных записок», подчинен «редакторскому диктату». М. Вишняк писал об этом так: «Мы не обманывались в том, что популярность журнал может приобрести лишь благодаря литературно-художественному своему отделу, а никак не общественно-политическому. <...> Наши литературно-художественные вкусы могли лишь косвенно влиять на редактирование журнала. К общественно-политическому же отделу “Современных записок" мы имели прямое и непосредственное отношение. Здесь пристрастие могло легче сказаться. Однако и тут мы старались быть терпимыми и не заг- лушать голосов с нами несогласных» [Вишняк, 1972, с. 354]. Важно подчеркнуть следующий любопытный эффект: с одной стороны, казалось бы, «неуправляемый» художественный раздел должен был бы повышать смысловую энтропийность журнального текстуального пространства, с другой - именно эта «автономность» отражает не «замысел» издания, который может так и остаться лишь желаемой возможностью, а реализацию этого замысла внутри совершенно конкретных текстов или же на конкретном текстуальном пространстве журнала.

Ни один не только эмигрантский, но и вообще российский журнал не мог похвалиться таким богатым сосредоточием текстов крупнейших поэтов, прозаиков и драматургов (М. Вишняк насчитывает 42 «беллетриста, романиста и драматурга»). Это большая часть эмигрантских произведений И.А. Бунина (включая знаменитую «Жизнь Арсеньева»), подавляющее большинство романов и повестей М.А. Алданова (включая его романные циклы), почти все произведения В.В. Набокова «русского» периода, романные циклы Д.С. Мережковского, тетралогия Б.К. Зайцева «Путешествие Глеба», а также другие его романы и повести, романы И.С. Шмелева, романы и повести М.А. Осоргина (включая уже ставший классическим «Сивцев Вражек»), «Преступление Николая Летаева» Андрея Белого, «Жанетта» А.И. Куприна, повести и рассказы Г. Газданова, Н. Берберовой и многих других «молодых» и «старых» авторов. Достаточно внушительны подборки стихотворений как поэтов «старшего» (Вяч.И. Иванов, К.Д. Бальмонт, 3.Н. Гиппиус, М.И. Цветаева, В.Ф. Ходасевич, Г.В. Адамович и др.), так и «молодого» (Н.Н. Берберова, Д. Кнут, Г.Н. Кузнецова, Е.Ю. Кузьмина-Караваева, А.С. Головина, И.Н. Голенищев-Кутузов, Ю.В. Мандельштам, В.А. Смоленский, Ю.К. Терапиано и др.) поколений. Эстетические и общественно-философские позиции перечисленных авторов не отличались гомогенностью. Разнообразна и тематика их произведений. Наша задача - определить их «общий знаменатель», поиск которого может осуществляться как на формальном, так и на семантическом (содержательном) уровнях. Если говорить о первом из них, то все тексты 
относятся к художественному дискурсу «Современных записок». Термин «дискурс» используется нами для формального различения художественных и нехудожественных журнальных текстов, позволяет провести элементарную дифференциацию между художественной философско-публицистической, критической и мемуарной «манерами письма», частично совпадающими с внутрижурнальным членением на «разделы» издания. Методологически такая сегрегация уже была апробирована в работе И.В. Силантьева «Газета и роман: Риторика дискурсных смешений» [Силантьев, 2006], где справедливо утверждается, что «тексты газеты образуют ансамбль, говорящий разными и многими голосами - голосами различных и многих дискурсов. ...голосами не авторов и не просто субъектов мысли и высказывания, а голосами дискурсов, воплощенных и в авторстве, и в субъективности высказываний, и в текстах собственно» [Силантьев, 2006, с. 56]; «...замыкание газеты в рамках одного и единого дискурса противоречит самой природе газеты как ансамбля дискурсов с их разноуровневой иерархией, с их перекличкой и разноголосицей» [Силантьев, 2006, с. 63].

Пользуясь почти эксклюзивным правом разработки термина «дискурс», новейшие лингвистические направления ищут область его функционирования прежде всего в речевой деятельности (подробно о различных пониманиях дискурса см.: [Карасик, 2002, с. 270-287]). Вслед за Д. Шифрин М. Макаров выделяет три основных подхода к трактовке этого понятия: «Первый подход, осуществляемый с позиций формально или структурно ориентированной лингвистики, определяет дискурс просто как “язык выше уровня предложения или словосочетания" < ...> Второй подход дает функциональное определение дискурса как всякого "употребления языка" <...> Этот подход предполагает обусловленность анализа функций дискурса изучением функций языка в широком социокультурном контексте. <..> Д. Шифрин предлагает и третий вариант определения, подчеркивающий взаимодействие формы и функции: “дискурс как высказывания"... Это определение подразумевает, что дискурс является не примитивным набором изолированных единиц языковой структуры “больше предложения”, а целостной совокупностью функционально организованных, контекстуализованных единиц употребления языка» [Макаров, 2003, с. 86]. Уже эти подходы демонстрируют стремление ученых к селекции дискурса и текста, что не может долго оставаться незамеченным при общей тенденции к синтезу гуманитарных научных методов: «Термин дискурс, понимаемый как речь, “погруженная в жизнь", в отличие от текста, обычно не относится к древним текстам, связи которых с живой жизнью не восстанавливаются непосредственно, хотя в последнее время наметилась тенденция к применению методологии дискурс-анализа и самого термина дискурс к языковому материалу разной культурно-исторической отнесенности, например, Библейским текстам и апокалиптической литературе, а также произведениям литературы, текстам массовой культуры, психоанализу» [Макаров, 2003, с. 88]. При таком взгляде на дискурс подразумевается, что в один текст могут быть инкорпорированы различные дискурсы, например, религиозный и юмористический дискурсы являются «составляющими» текста романа М. Булгакова «Мастер и Маргарита» или философско-публицистический дискурс является заметным «имплантантом» в ткань дилогии Д.С. Мережковского о Древнем Востоке. Не умаляя значения этих во многом претендующих на трюизм замечаний, еще раз отметим, что мы используем термин «дискурс» для формального разграничения множества разноприродных текстов, напечатанных в «Современных записках». В смысловое пространство журнала нами включаются и полные варианты произведений, частично или с сокращениями различной степени увидевших свет на страницах издания (вскоре после журнальной публикации их большая часть была выпущена отдельными книгами в одноименном издательстве, но именно первое знакомство с текстом в выпуске подталкивает читателя к прочтению его полного варианта), что в какой-то степени подразумевает апелляцию к тексту-как-речи - журнальному тексту, «договариваемому» в книге.

Мы не будем сейчас останавливаться подробно на имплицитных свойствах художественного дискурса (об этом см.: [Женетт, 1998; Тюпа, 2002]), отметим лишь то, которое 
является одним из фундаментальных, - это принципиальная и обязательная фикциональность художественного дискурса, невозможность его верификации. «Поэтому ему [автору $-A$. М., И. $Ш$.] принадлежит только целое текста, смыслообразно скомпанованное из речений по большей части вымышленных субъектов речи: “чужих” ему или “своих других” для него. “От себя” писатель высказывается лишь в текстах, лишенных художественности» [Тюпа, 2002, с. 8]. Обозначив это важное в контексте нашего исследования свойство, обратимся ко второму - семантическому - уровню, на котором возможен поиск «общего основания» как текстов художественного дискурса «Современных записок», так и остальных.

В самом широком смысле поиск «общего основания» всегда так или иначе ведется на «территории» интертекстуальной методологии, но разработка интересующих нас вопросов в этом направлении неизбежно приведет не к тем результатам или, вернее, не даст результатов вовсе, прежде всего вследствие отсутствия реальной потребности таких разработок. Однако, оставляя основные ее механизмы и принципы «интертекстуальной» методологии в качестве обязательного фона исследования, обратимся к понятию текст, чтобы увидеть его в том аспекте, который соответствует нашим задачам.

Мы эксплицируем в литературе и шире - в культуре русского зарубежья некоторое проблемно-тематическое, образное, идейное и даже мифопоэтическое (мифологическое) единство, определяемое как «русский текст эмиграции». Он включает в себя ряд константных (ментальных, но закрепленных текстуально) комплексов, интенционально ориентированных на осмысление российских событий 1917 г., «фоном» которых выступают самые широкие пласты как русской, так и всемирной истории. Тем самым русский текст, как и «петербургский», ограничен не столько локально (Россия), сколько «перспективно» («судьбы мира» в целом), и имеет не столько тематическое (тексты о России), сколько проблемное «измерение» (тексты, в которых «российская» проблематика мыслится как общечеловеческая и универсальная, а архетипические ситуации полностью приложимы к Рос- сии). Этот момент оговаривается, например, у В.Н. Топорова: «Петербургский текст есть текст не только и не столько через связь его с городом Петербургом (экстенсивный аспект темы), сколько через то, что образует особый текст, текст par excellence, через его резко индивидуальный (“неповторимый”) характер, проявляющийся в его внутренней структуре (интенсивный аспект)» [Топоров, 1995, с. 280]. «Русский текст» охватывает собой абсолютное большинство эмигрантских текстов самого различного плана, принадлежащих самым разным дискурсам, обеспечивая им особую гомеоморфность, а в специфических условиях (будучи помещенными в единое текстуальное пространство, в частности, журнальное) делая возможным прочтение даже весьма «нейтральных» текстов с помощью именно своего «кода». Широту этого охвата в первую очередь демонстрирует поэтика заглавий тех эмигрантских текстов, которые с полным правом можно было бы назвать прецедентными. Простое перечисление заглавий, содержащих слова русский, Россия или родина, займет не одну страницу. Приведем лишь некоторые из них: «Мысли о России» Ф.А. Степуна, «На родине» М.В. Вишняка, «Пути России» И.И. Бунакова-Фодаминского, «Я унес Россию» Р.Б. Гуля, «Истоки и смысл русского коммунизма» Н.А. Бердяева, «Письма о русской культуре» Г.П. Федотова, «Из размышлений о русской революичи» С.Л. Франка, «Миссия русской эмиграциии» И.А. Бунина, «Третья Россия» А. Ветлугина, «Затуманившийся мир и русский вопрос» В.Ф. Иванова, «Россия в кониялагере» И.Л. Солоневича. Большая часть только этих текстов либо появилась, либо получила отклики на страницах «Современных записок».

Следовательно, философско-публицистический дискурс (частично совпадающий с границами и второго журнального раздела «Культура и жизнь») «Современных записок» является доминирующим в экстраполяции стержневой проблемы русского текста - «Россия и революция». Он словно «заражает» этим «вирусом» менее идеологически маркированные тексты других дискурсов - художественного, критического, собственно-философского - но сам вскоре теряет свою «силу» вслед- 


\section{РАЗВИТИЕ И ФУНКЦИОНИРОВАНИЕ РУССКОГО ЯЗЫКА}

ствие изначальной смысловой энтропийности, хаотичности, неопределенности, неспособности предстать в виде более или менее стройного учения, идеи или мифа, «рассказа о России», что будет под силу лишь менее идеологизированному, но более семантически гибкому, «культурно живучему», оказывающемуся способным, словно Протей, не только принимать адекватные культурные формы, но даже создавать собственные культурные «матрицы», дискурсу художественному. Философскопублицистический дискурс словно передает художественному «гальванический заряд» основного смысла, чтобы самому, избегая первоначального бессильного пароксизма, вновь принять вернувшийся смысл стройным и обретшим в результате мутации невиданные ранее пропорции, стать - пусть лишь одним из важнейших - элементом в построении гармоничного целого.

Таким образом, мы можем говорить о трехуровневой дискурсивной структуре «Современных записок» (или вообще «толстых» журналов - с учетом культурно-исторической конкретики) как текстового образования. В качестве доминирующей дискурсивной практики выступает трансдискурсивность, позволяющая осуществлять эффективную осцилляцию смыслов от одного дискурса к другому.

\section{Дискурсивные практики новых медиа}

Социальные медиа на современном этапе своего развития не только испытывают влияние разнородных факторов, но и сами оказывают конституирующее воздействие на социальную реальность, в частности, на коммуникативные процессы. При этом возникает принципиальная необходимость не только в установлении границ этого влияния, его естественных ограничителей, направления и механизмов, но и в демонстрации механизмов функционирования дискурсивных практик в совершенно иной коммуникативной модели.

Положение о конституирующей потенции социальных медиа относительно самой сферы социального представляется синтезом нескольких постулатов, опирающихся на две разнонаправленные тенденции. С одной стороны, интернет-коммуникациям вполне спра- ведливо приписывалась роль симулякра, повторяющего процессы объективной реальности: «Компьютеризация повседневной жизни вводит в обиход виртуальную реальность в качестве компьютерных симуляций реальных вещей и поступков» [Иванов, 2000, с. 13]. Представленная цитата из научной работы 2000 года не отражает комплексных изменений, произошедших в коммуникативной парадигме за последние двадцать лет, во многом связанных с эволюцией социальных медиа.

С другой стороны, при дискурсивном подходе к социальным медиа абсолютизируется их конституирующее значение как одной из ведущих коммуникативных практик. «Дискурс - это форма социального поведения, которая участвует в формировании социального мира (включая знания, людей и социальные отношения) и, таким образом, в поддержании и сохранении социальных паттернов» [Йоргенсен, Филлипс, 2008, с. 24]. Последние могут не только сохраняться, но и трансформироваться в процессе изменения их границ. Так, медийный дискурс с появлением новых коммуникативных форм, в том числе и социальных медиа, претерпел значительные изменения, которые не могли не отразиться на социальной сфере, во многом конституируемой традиционными и новыми средствами массовой информации.

Рассматривая социальные медиа как значимую составляющую медийных коммуникативных практик, мы придерживаемся идеи конвергенции, не наделяя их, однако, тотальным конституирующим влиянием.

Отметим, что в приведенном выше определении дискурса симптоматичен акцент на поддержании и сохранении социальных паттернов. Он отражает ориентацию на описание ситуации в марксистских и постмарксистских терминах. В этом случае для трансформации дискурса, в том числе медийного, необходим конфликт дискурсов, в котором доминирующий ориентирован на уже существующие практики, а вступающий с ним в борьбу - на новые.

Стремление экстраполировать выводы из теории, касавшейся экономики, на сферу символов, знаков и коммуникаций продиктовано необходимостью описать новое по своей сути явление в привычных формулиров- 
ках. Отсюда и тяготение к соответствующим метафорам: «Технологическая инфраструктура, на которой строится сеть, определяет новое пространство почти так же, как железные дороги определяли “экономические регионы" и “национальные рынки” индустриальной экономики» [Кастельс, 2000, с. 110]. Подобный подход оправдан на первых этапах осмысления комплексного явления, но по мере развития самой системы и научных знаний о ней требует серьезной модификации на всех уровнях.

Тезис об оппозиционности старого и нового, борьбе дискурсов, обладая рядом существенных недостатков, имеет в то же время серьезный эвристический потенциал. С его помощью можно диалектически обосновать коннотации инаковости, которые преобладали в Рунете с момента его появления. Противопоставление первых блогеров институализированным СМИ на несколько лет задало магистральное направление исследований, посвященных этому феномену. Вопрос о принципиальной взаимозаменяемости «низовой» активности блогеров и работы средств массовой информации лишь относительно недавно перешел в плоскость выстраивания единой коммуникативной системы. Немалую роль в этом сыграли и работы, посвященные дискурс-анализу, ориентированные на постмарксистский подход, при котором постулируется гегемония старых коммуникативных моделей, сменяющаяся борьбой с новыми парадигмами. При этом существующие коммуникативные модели якобы утверждают свою гегемонию посредством определенных языковых и речевых практик, задают идеологические паттерны, претендующие на всеобщность и исключающие критический подход. Альтернатива создается с позиций критики идеологии.

Таким образом, подход, основанный на представлениях о борьбе дискурсов, обладает как рядом достоинств, так и недостатками, главным из которых становится малая включенность иных социальных факторов, которые якобы формируются внутридискурсивно.

Комбинацию дискурсов в текстах социальных медиа и их артикуляцию рассмотрим в контексте интертекстуальности, отсылающей нас к теории диалогичности отечествен- ного ученого М.М. Бахтина (см.: [Бахтин, 1979]), а также интердискурсивности, то есть «процесса когнитивного уровня, взаимодействия в сознании носителя языка надтекстовых единиц: дискурсов, семиотических кодов разного уровня» [Прокофьев, 2013, с. 77]. При такой методологической позиции представления о борьбе дискурсов и гегемонии одного из них, связанного с доминирующими социальными практиками, заменяются картиной о взаимодействии дискурсов. Датские исследователи М.В. Йоргенсен и Л.Д. Филлипс пишут по этому поводу: «Если в исследовании концентрироваться на строе дискурса, а не на отдельном дискурсе, то взаимодействие между дискурсами внутри дискурсстроя попадает в фокус внимания. Это дает преимущества, поскольку именно в таком взаимодействии социальные последствия становятся наиболее очевидными: когда два или более дискурсов в одной и той же области представляют различный взгляд на мир, исследователь может задаться вопросом: каковы последствия того, что один взгляд будет принят вместо другого» [Йоргенсен, Филлипс, 2008, с. 237].

При применении дискурс-анализа в сфере социальных медиа необходимо ответить на вопрос о границах дискурса социальных медиа. Он (дискурс) является органической частью общего медийного дискурса, пределы которого на современном этапе общества остаются размытыми. Медиатизацию, то есть «качественные изменения социальных коммуникаций, вызванные воздействием медиа, которые из институции, отражающей жизнь, становятся фактором, определяющим существенные моменты жизни общества и современной личности» [Шмелева, 2015, с. 145], необходимо рассматривать как один из важнейших феноменов в контексте изучения связи медиадискурса и социальной реальности. Практически все традиционные сферы общественной жизни, начиная с политики и заканчивая спортом, испытывают значительное влияние медийной среды. Последнее при этом не носит аннексирующего характера, а скорее двунаправленно. На дискурс социальных медиа, входящий в общий медийный дискурс, также распространяется указанная неопределенность: чем отчетливее будут в нем видны 
включения из иных социальных практик, тем сильнее он сам будет влиять на них.

В этом контексте возникает необходимость выявления особенностей коммуникации в сообществах СМИ, а также не связанных с профессиональной журналистикой. На первый план при этом выходят вопросы артикулирования определенных дискурсов в текстах, их возможной полифонии или доминирования, а также конструирования определенных идентичностей и социальных групп.

Исследованный эмпирический материал - сообщества профессиональных СМИ («Высота 102» и РИАЦ), а также паблики, не связанные с профессиональными медиа, но ориентированные на распространение социально значимого контента («Типичный Волгоград» и «НЕтипичный Волгоград»), - обнаруживает полидискурсивность, присущую социальным сетям в целом. Наиболее часто представленными становятся такие дискурсы, как медийный, консьюмеристкий, а также направленный на формирование местной идентичности в социокультурном пространстве региона.

Медийный дискурс явно преобладает в сообществах профессиональных средств массовой информации. Например, в так называемой «шапке» сообщества «Высота 102» (5,3 тысячи подписчиков в социальной сети «ВКонтакте») постулируется: «“Высота 102” признанный и широко цитируемый источник оперативной и достоверной информации, который прочно занимает первые позиции по популярности среди новостных сайтов Волгоградской области». При этом включения иных дискурсов минимальны. Гипотетически это может служить одной из причин малой популярности сообществ региональных средств массовой информации в пространстве социальных сетей. Полидискурсивность в этом случае выражена скорее имплицитно.

В то же время сообщества, распространяющие социально значимую информацию, но при этом не связанные с профессиональными средствами массовой информации, представляют себя комплексно, сочетая возможности разных дискурсов. Например, администрация сообщества «Типичный Волгоград» (в социальной сети «ВКонтакте»), ориентированного на распространение социально значимого контента $(247,5$ тысяч пользо- вателей), в сведениях о ресурсе указывает следующее: «Типичный Волгоград - сообщество, где находятся люди с твердым убеждением, что Волгоград самый лучший и самый красивый город. Типичный Волгоград сообщество, где собраны самые активные, умные и продвинутые волгоградцы. Типичный Волгоград - для людей, интересующихся событиями Волгограда и всем, что связано с городом». Далее следуют сведения о рубриках, сопровождаемые тематическими хэштегами, а также контакт администратора и дата создания.

Полидискурсивность, характерную для сообществ в пространстве социальных медиа, можно выявить уже на стадии анализа информации о сообществе. Так, первое предложение Типичный Волгоград - сообщество, где находятся люди с твердым убеждением, что Волгоград самый лучший и самый красивый город выражает региональную идентичность, актуализируя патриотический дискурс. Высказывание Типичный Волгоград сообщество, где собраны самые активные, умные и продвинутые волгоградиы активизирует консьюмеристкий дискурс: сообщение об образе, который придает использование того или иного продукта, в том числе информационного, широко распространено в рекламных практиках. Третье предложение Типичный Волгоград - для людей, интересуюшихся событиями Волгограда и всем, что связано с городом актуализирует медийный дискурс и представляет рассматриваемое сообщество как новостную площадку. Наконец, контактные данные по всем вопросам (в том числе по сотрудничеству) вновь активизируют консьюмеристский дискурс. Таким образом, полидискурсивность проявляет себя даже на весьма ограниченном текстовом отрезке.

Симбиоз трех дискурсов (патриотического, медийного и консьюмеристского) во многом формирует облик сообщества. Отметим, что ни один из указанных дискурсов не претендует на статус доминирующего.

Интердискурсивность, наблюдаемая в той или иной степени в каждом из рассмотренных случаев, подкрепляется включенностью сообществ СМИ или пабликов, ориентированных на распространение социально 
значимой информации, в общий контекст социальных медиа и соответствующий дискурс, что заостряет конфликт между ориентацией на традиционные коммуникативные модели, присущие сообществам некоторых региональных средств массовой информации, и самим информационным пространством, в котором они их репрезентируют. Такое противоречие согласуется с представлениями о борьбе старого и нового, широко распространенными в дискурс-анализе, а также с широким комплексом социальных факторов, детерминирующих серьезные изменения в коммуникативной и когнитивных моделях как потребителя информационного продукта, так и его производителя.

Выявленная нами интердискурсивность присуща не только сообществам, связанным с медийной сферой, но и пространству социальных сетей в целом. В случае с рассмотренными пабликами она обладает несколькими значимыми характеристиками.

Во-первых, это постепенно нарастающее влияние консьюмеристского дискурса. Если на ранних этапах своего функционирования та или иная форма социальных медиа менее институционализирована, то со временем к набирающей популярность площадке начинают проявлять интерес не только общественные объединения, но и политические акторы, коммерческие организации. Консьюмеристкий дискурс оказывается одним из наиболее значимых, связанных с желанием монетизировать накопленный социальный капитал. Если в системе СМИ этот механизм давно отлажен, то в социальных медиа происходит поиск наиболее адекватных форм, соответствующих измененной коммуникативной модели.

Во-вторых, это формирование определенной идентичности (в нашем случае региональной) посредством диалогичности. Социальные сети представляются пространством максимально открытой коммуникации. Если традиционные средства массовой информации оперировали понятием целевой аудитории, определенной на основе социально-демографических показателей, то в данном случае подписчики сами участвуют в формировании общности. Администраторы страниц выступают в качестве модераторов, во многом задающих тематику группы и границы, которые мо- гут быть как строго установленными, так и размытыми. В любом случае трактовочнокомментарийный комплекс, образующийся вокруг публикаций, во многом задает характер формируемой общности, дополняя смыслы публикаций или видоизменяя их.

В-третьих, это интердискурсивность. Она свидетельствует о принципиальной незавершенности процесса выстраивания коммуникативной модели в сообществах, ориентированных на продуцирование социально значимого контента, о ее поливариативности и в какой-то мере ризомности. Наличие доминирующего медийного дискурса не исключает полностью продолжающегося процесса ее выстраивания, не задает строгой иерархии, хотя во многом и определяет границы коммуникативной модели. Включение иных дискурсов становится причиной флуктуаций, во многом детерминирующих неповторимый облик того или иного ресурса в пространстве социальных сетей. Отчасти это можно связать с описанной нами выше ситуацией борьбы дискурсов, однако в данном случае скорее наблюдается их симбиоз, возникший под влиянием целого ряда разнообразных факторов: особенностей коммуникаций, технических детерминантов, социокультурных включений и др.

Подводя итог рассмотрения социальных медиа в контексте дискурс-анализа, необходимо отметить, что такой подход представляется наиболее перспективным в том случае, если он будет подкреплен иными методами, способными обрисовать более полную картину происходящего на данном этапе развития изучаемой площадки. Категории дискурсов раскрывают многие сущностные черты объекта, оставляя при этом другие, не менее важные, на периферии исследования. Система социальных медиа является многослойным образованием, требующим соответствующего подхода к его изучению, отличающегося не мозаичностью, но стремлением осмыслить объект в его комплексности. Углубленный анализ отдельных сторон социальных медиа, связанный с применением того или иного научного метода, должен быть сопряжен с максимально объективной оценкой полученного знания и выстраиванием на его основе единой системы представлений об объекте. 


\section{Заключение}

Медийные дискурсивные практики, будучи гетерогенными структурами, разными способами не только корреспондируют, но и формируют семантический потенциал конкретных медиа. В традиционных медиа, как видно на примере анализа классического «толстого» журнала «Современные записки», ведущей дискурсивной практикой выступает трансдискурсивность. Именно она позволяет осуществлять эффективную осцилляцию смыслов от одного дискурса к другому.

В новых медиа приоритетными оказываются такие практики, как полидискурсивность и интердискурсивность. Они формируют аутентичные коммуникативные модели в ситуации глобальной трансформации медийного пространства. При этом доминирующими становятся такие дискурсы, как медийный, консьюмеристкий, а также направленный на формирование идентичности в социокультурном пространстве.

\section{СПИСОК ЛИТЕРАТУРЫ}

Азаров Ю. А., 2002. Журнал «Современные записки»: Партийная редакция и литература // Русская культура XX века на родине и в эмиграции: Имена. Проблемы. Факты / Под ред. Т. П. Буслаковой, Е. А. Ивановой, М. В. Михайловой. М. : Филологический факультет МГУ им. М.В. Ломоносова. Вып. 2. С. 279-297.

Бахтин М. М., 1979. Эстетика словесного творчества. М. : Искусство. 445 с.

Вишняк М. В., 1972. «Современные записки» // Русская литература в эмиграции. Питтсбург : Отдел славянских языков Питтсбургского университета. С. 353-360.

Женетт Ж., 1998. Повествовательный дискурс // Фигуры : в 2 т. М. : Изд-во им. Сабашниковых. Т. 2. С. 60-282.

Иванов Д. В., 2000. Виртуализация общества. СПб. : Петербургское Востоковедение. 96 с.

Йоргенсен М. В, Филлипс Л. Д., 2008. Дискурс-анализ: теория и метод. Харьков : Гуманитарный центр. $352 \mathrm{c}$.

Карасик В. И., 2002. Языковой круг: личность, концепты, дискурс. Волгоград : Перемена. $477 \mathrm{c}$.

Кастельс М., 2000. Информационная эпоха: экономика, общество и культура. М. : ГУ ВШЭ. 608 с.
Макаров Н. Л., 2003. Основы теории дискурса. М. : ИТДК «Гнозис». $280 \mathrm{c}$.

Прокофьев Г. В., 2013. Категория интердискурсивности как средство организации медиадискурса // Вестник Томского государственного педагогического университета. № 5 (133). C. 77-79.

Силантьев И. В., 2006. Газета и роман: Риторика дискурсных смешений. М. : Языки славянской культуры. 224 с.

Топоров В. Н., 1995. Миф. Ритуал. Образ: Исследования в области мифопоэтического: Избранное. М. : Издательская группа «Прогресс»«Культура». $624 \mathrm{c}$.

Тюпа В. И., 2002. Художественный дискурс: (Введение в теорию литературы). Тверь : Изд-во Тверск. гос. ун-та. $80 \mathrm{c.}$

Шмелева Т. В., 2015. Медиатизация как феномен современной культуры и объект исследования // Вестник Новгородского государственного университета имени Ярослава Мудрого. Серия: Массовая Коммуникация. Журналистика. Средства массовой информации (СМИ). № 90. С. 145-148.

\section{REFERENCES}

Azarov Yu.A., 2002. The Journal Sovremennye zapiski: Party Edition and Literature. Buslakova T.P., Ivanova E.A., Mikhaylova M.V., eds. Russkaya kultura XX veka na rodine i v emigratsii: Imena. Problemy. Fakty. Vyp. 2 [Russian Culture of the $20^{\text {th }}$ Century in the Homeland and in Emigration: Names. Problems. Data. Vol. 2.]. Moscow, MGU Publ., pp. 279-297.

Bakhtin M.M., 1979. Aesthetics of Verbal Creativity. Moscow, Iskusstvo Publ. 445 p.

Vishnyak M.V., 1972. Modern Notes. Russkaya literatura $v$ emigratsii [Russian Literature in Exile]. Pittsburgh, Otdel slavyanskikh yazykov Pittsburgskogo un-ta, 1972, pp. 353-360.

Genette G., 1998. Narrative Discourse. Genette G. Figury. T. 2. [Figures. Vol. 2.]. Moscow, Izd-vo imeni Sabashnikovykh, 1998, pp. 60-282.

Ivanov D.V., 2000. Community Virtualization. Saint Petersburg, Peterburgskoe Vostokovedenie Publ. 96 p.

Jorgensen M.V., Phillips L.D., 2008. Discourse Analysis: Theory and Method. Kharkov, Gumanitarnyy tsentr Publ. 352 p.

Karasik V.I., 2002. Language circle: personality, concepts, discourse. Volgograd, Peremena Publ. $477 \mathrm{p}$.

Castells M., 2000. Information Age: Economy, Society and Culture. Moscow, Vysshaya shkola ekonomiki Publ. 608 p. 
Makarov N.L., 2003. Fundamentals of the Theory of Discourse. Moscow, Gnozis Publ. 280 p.

Prokofyev G.V., 2013. The Category of Interdiscourse as a Means of Organizing Media Discourse. Vestnik Tomskogo gosudarstvennogo pedagogicheskogo universiteta [Tomsk State Pedagogical University Bulletin], no. 5 (133), pp. 77-79.

Silantyev I.V., 2006. Newspaper and Novel: The Rhetoric of Discourse Mixes. Moscow, Yazyki slavyanskoy kultury Publ. 224 p.
Toporov V.N., 1995. Myth. Ritual. Image: Research in the Field of Mythopoetics. Selected Works. Moscow, Progress-Kultura Publ. 624 p.

Tyupa V.I., 2002. Fiction Discourse: (Introduction to Literary Theory). Tver, Izd-vo Tverskogoun-ta. 80 p.

Shmeleva T.V., 2015. Mediatization as a Phenomenon of Modern Culture and an Object of Research. Vestnik Novgorodskogo gosudarstvennogo universiteta imeni Yaroslava Mudrogo [Vestnik of Yaroslav the Wise Novgorod State University], no. 90 , pp. $145-148$.

\section{Information about the Authors}

Aleksandr V. Mlechko, Doctor of Sciences (Philology), Professor of Department of Russian Philology and Journalism, Volgograd State University, Prosp. Universitetsky, 100, 400062 Volgograd, Russia, av_mlechko@volsu.ru, https://orcid.org/0000-0003-1329-8478

Ivan N. Shamaev, Postgraduate Student, Department of Russian Philology and Journalism, Volgograd State University, Prosp. Universitetsky, 100, 400062 Volgograd, Russia, vonschwarz@mail.ru, https://orcid.org/0000-0001-8994-4208

\section{Информация об авторах}

Александр Владимирович Млечко, доктор филологических наук, профессор кафедры русской филологии и журналистики, Волгоградский государственный университет, просп. Университетский, 100, 400062 г. Волгоград, Россия, av_mlechko@volsu.ru, https://orcid.org/0000-00031329-8478

Иван Николаевич Шамаев, аспирант кафедры русской филологии и журналистики, Волгоградский государственный университет, просп. Университетский, 100, 400062 г. Волгоград, Россия, vonschwarz@mail.ru, https://orcid.org/0000-0001-8994-4208 